\title{
Transit and Handling Losses of Rice in Public Distribution of Andhra Pradesh, India- A Case Study
}

\author{
S. Vishnu Vardhan*, S.V.S. Gopala Swamy, D. Sandeep Raja and B. John Wesley
}

Post Harvest Technology Centre, Bapatla- 522 101, Andhra Pradesh, India

Acharya N.G. Ranga Agricultural University, India

*Corresponding author

\section{A B S T R A C T}

\begin{tabular}{l}
\hline Ke y w or d s \\
$\begin{array}{l}\text { Assessment; Transit } \\
\text { and handling loss, } \\
\text { Rice, Public } \\
\text { distribution system; } \\
\text { MLS point }\end{array}$ \\
\hline Article Info \\
\hline $\begin{array}{l}\text { Accepted: } \\
\text { 22 June } 2020 \\
\text { Available Online: } \\
\text { 10 July } 2020\end{array}$ \\
\hline
\end{tabular}

Andhra Pradesh State Civil Supplies Corporation Ltd. (APSCSCL) plays significant role in providing food security through distribution of rice to the vulnerable section of people under targeted public distribution system through Mandal Level Stock (MLS) Points. The physical and social system in which the rice commodity moves from buffer storage warehouse to MLS point (stage I) and MLS point to fair price shop (stage II) and how it is being handled was studied by selecting one MLS point in each district. Thus, a total of 13 MLS points were selected. Data of monthly receipts and issues for a period of 5 months were recorded. For estimating transit and handling losses during Stage I transport and Stage II transport, $100 \%$ weighment was made. Data for stage I transportation and stage II transportation were collected and analyzed using statistical package SPSS 16.0 for tests of significance. A total quantity of 28391.47 MT of rice was handled during the study period for assessment of losses. Average total transit and handling losses were estimated to be $0.276 \%$. Economic loss due to transit and handling losses extrapolating to the state of Andhra Pradesh as a whole was estimated as Rs. 182.11 million per annum.

\section{Introduction}

India's food subsidy system has been a major component social welfare programme ensuring the reach of food grains at affordable prices to the economically weaker sections of the society, helping to reduce malnutrition, ensuring price stability and thus food security (World Bank, 1986) in the country. The governments have perceived that the supply of rice to the poor families at cheaper price is fundamental importance to ensure food security through the welfare schemes like Antyodaya Anna Yojana (AAY), Annapurna (AP) etc. The outflows on account of the welfare programmes have remained a fastest growing expenditure in budget of India and the supply of rice under subsidy scheme happened to be the largest of these programmes in terms of costs (World Bank, 1987). 
The central and state governments share the responsibility of regulating Targeted Public Distribution System (TPDS), while the central government is responsible for procurement, storage, transportation and bulk allocation of food grains and state government's responsibility lies with identifying the poor and distributing monthly allocated rice to them . The state of Andhra Pradesh has one of the largest food subsidy programmes in India that has created a relatively effective social safety net yet takes large contribution from government budget (Rao, 1993). On behalf of the state government, the Andhra Pradesh State Civil Supplies Corporation Ltd., (APSCSCL) plays significant role in providing food security through distribution of rice to the vulnerable section of people in the state. It is the responsibility of the APSCSCL to deliver allocated quantities of rice to the poor under TPDS at the door steps through Fair Price Shop (FPS) dealers through efficient transportation, storage and delivery of stocks. Mandal Level Stock (MLS) point is a godown that is used for receipt and issue of stocks and for short term storage.

The state currently draws huge quantities of food grains from the central allotment and also encounters an enormous rice subsidy bill. The subsidy incurred on rice by the APSCSCL reached Rs 23,800 million in 2015-16 fiscal as against Rs 21,180 million in 2014-15 (CAG, 2017). It can be perceived that the cost of rice paid to Food Corporation of India (FCI) constitutes the largest part of APSCSCL's expenditure on rice subsidy. It was observed that subsidised rice accounts for about 88 per cent of the total trading expenses and 99.5 per cent of total APSCSCL subsidy (Surajit, 2009); reflecting the crucial financial implications in the APSCSCL's finance.

AP State Civil Supplies Corporation is operating about 268 Mandal Level Stock
(MLS) points. Every month, APSCSCL handles about 0.22 million MT of rice for distribution under TPDS / other welfare schemes. Depending upon monthly requirement and as per the allotment given by the Commissioner (Civil Supplies Department) and District Supply Officer of each district concerned, stocks are moved to MLS Points and from there transported to Fair Price shops. There are two stages of transportation of PDS commodities for reaching the stock up to the door steps of the FPS dealers. Under stage I transportation, stocks are transported from buffer storage godowns like FCI/ Central Warehousing Corporation (CWC)/ State Warehousing Corporation (SWC) godowns to MLS Points. Under stage II transportation, stocks are moved from MLS Points to FP shops (Figure $1)$. The MLS points run by APSCSCL are mostly in the available godowns which are semi scientific or unscientific. Therefore, some amount of storage and transit losses are inevitable during regular operations conducted by the Corporation. However, accurate estimations of the magnitude of losses are lacking. Hence, the present study was conducted by the Post Harvest Technology Centre, Bapatla to estimate the extent of transit and handling losses that were occurring at selected MLS Points during stage I and stage II transportation of rice

\section{Materials and Methods}

The distribution of rice under public distribution system involves production, processing and distribution of rice following complex movement which is always locality specific and usually very complex consisting of many stages in the form of a chain. In this present study the loss estimation was confined to the channel " $F C I / C W C / S W C$ buffer storage godowns $\rightarrow$ MLS points $\rightarrow$ FP shop dealers." 
The study on physical and social system in which rice moves from stage I to stage II transportation was covered, identifying how commodities were handled and how many times they were handled.

\section{Selection of MLS Points}

The transactions of APSCSCL are being operated through about 268 MLS points across the 13 districts located in different agro climatic zones of the state and each MLS point is attached to 3-5 mandals. For all the practical purposes, one MLS point in each district was randomly selected by APSCSCL for the study (Table 1). While selecting the MLS points, the factors such as operational feasibility, $100 \%$ weighment facilities were taken into consideration. Thus, a total of 13 MLS points were selected across the state one per each district.

A standard stock weight of 500 MT per month was adopted in most of MLS points. (Exception to Srikakulam and Podalakuru MLS points, where godown capacity is less than $500 \mathrm{MT}$ )

Weighment of stocks on $100 \%$ basis at MLS points during receipt and issues was carried out. In five MLS points viz., Srikakulam, Vizianagaram, Marripalem, Guntur and Punganur, 3/3.5 MT capacity platform scales were used for weighment of stocks receipts and issues. However, MLS Points of Kadapa, Vuyyuru, Rajahmundry and Singarayakonda used weighbridge for receipts and platform scale for issues. Further Hindupur, Kurnool, Tadepalligudem and Podalakuru MLS points used weighbridges for both receipts and issues. All the platform scales and weigh bridges were verified by the Legal Metrology Department.

For estimating transit loss from buffer stock point to MLS point (Stage I transport) and MLS point to FP shops (Stage II transport), $100 \%$ weighment was made to ascertain any loss. The condition of road, truck, pilferage, siphoning during transit was also considered during the study.

For estimating handling loss, during loading and unloading from truck and during stacking, spilled grains which cannot be recollected and unfit for consumption was recorded as loss.

Data collection schedules for stage I transportation and stage II transportation were prepared (Nanda et al., 2012). Data were collected as per schedules as per monthly transactions of receipts and issues at all thirteen MLS points consecutively for five months i.e., a total of 65 observations were collected.

Data collection and recording of the all the observations were carried out in presence of respective MLS point incharges.

\section{Transit loss}

Transit loss in this paper refers to the loss that may arise during transport from $\mathrm{FCI} / \mathrm{CWC}$ Buffer Storage Godown (BSG) and receipt of the stocks at MLS point. Transit loss is detected by measuring actual difference between quantity dispatched from buffer storage godown (CWC/SWC/FCI) and quantity received at MLS point. This also includes spilled grains that are unfit for consumption. For the purpose of this study, the discrepancy in quantity of rice received from buffer storage godowns due to different modes of weighment system i.e., weighbridge (50/60/100 MT) and platform scale (3/ 3.5/ 4 MT) were also included under transit losses.

Per cent transit loss $=$ $\frac{\text { Quantity despatched at stage I-Quantity received at MLS point }}{\text { Quantity despatched at stage I }} \times 100$ 


\section{Handling loss}

Handling loss includes spilled rice quantity that may be due to multiple handling of rice bags during unloading from truck, stacking inside the godowns, re-bagging, salvaging, standardization as may be necessary and destacking and loading the same at the time of delivery that are unfit for consumption. In this study, the losses that may arise due to bad condition of godown, due to insect, rodents, birds during transient storage were included under handling losses. Further, quantitative losses due to pilferage or siphoning were also considered in handling losses.

Per cent handling loss $=$

Quantity received at MLS point-Quantity issued to FPS

Quantity received at MLS point

$\times 100$

The data collected were checked for functional consistency and scrutinized for any discrepancies and errors and was analyzed using statistical package SPSS 16.0 for test of significance.

\section{Results and Discussion}

Based on the data collected from 13 MLS Points, loss assessment was undertaken. The pattern of loss and factors influencing were also recorded during the period from October 2017 to February 2018.

\section{MLS point wise transit and handling losses}

A quantity of 28391.47 MT of rice was handled during the study period for assessment of losses. It was observed that there has been a considerable loss during Stage I and stage II transportation. Average transit and handling losses in the select MLS points were in range of 0.08 to $0.505 \%$ and 0.04 to $0.34 \%$, respectively. Average total transit and handling losses in select MLS points were estimated to be $0.276 \%$ (Table 2). It was observed that Vuyyuru MLSP recorded highest average transit losses while Kurnool MLSP recorded highest average handling losses.

It was reported that a relatively high quantity of loss of grains $(0.80 \mathrm{~kg}$ /quintal i.e., $0.8 \%)$ when trucks are used for transport as compared to other modes of transport Kannan et al., 2013). In South-East Asia, 2-10 per cent losses during handling and transportation of rice was reported (Alavi et al., 2012). Transport losses in case of rice and wheat at farm level were estimated to be 0.764 and $0.656 \%$, respectively in Karnataka (Basavaraja et al., 2007).

The post-harvest losses in wheat were 8.0 per cent which were majorly caused by insects $(3.0 \%)$ and rodents (2.5\%), whereas the transport losses were estimated at 0.5 per cent only (Sreeramulu et al., 2005). Post-harvest losses in paddy were reported that total loss in farm operations at national level was 4.67 per cent mainly contributed by harvesting and threshing operations.

The loss during storage was at different channels was 0.86 per cent and total losses were 5.53 per cent. Field level transport losses for paddy from field to market was estimated as $0.09 \%$ (Jha et al., 2015). Improper handling and bad transportation facilities might lead to considerable loss of grains produced.

Statistical analysis of the data suggested that there were significant difference among various MLS points regarding transit as well as handling losses. However, when effect of months was considered, transit losses were found to be significant @ 1\% level when temporal effects were taken into consideration while handling losses were non-significant at $1 \%$ level (Table 3). 
Major factors responsible for transit and handling losses

This study has also assessed the specific constraints while handling rice at each MLS point. The major constraints as identified were: lack of knowledge on proper postharvest handling, inadequate godown capacity, lack of scientific storage facilities and sufficient staff to look after the transactions etc. However, the losses are heavily dependent on the specific conditions and local situations at a given MLS Point. The losses are not only resulted from a wide range of managerial and technical limitations in storage, transportation, infrastructural facilities, but also associated with transport distances during Stage I transportation.

\section{Different modes of weighment}

There were different modes of weighment either by Weighbridge (40/50/60/100 MT capacity) and/or by platform scales (3/3.5 MT capacity) (Plate 1). At some MLS Points, test weights were cross checked involving officers of Legal Metrology Department and calibrated at both buffer storage godown and MLS points. To ascertain variation of weights caused by weighment bridges at buffer godown storage issues and receipts of the stocks at MLS points was determined by comparing the tare weights of the trucks at both weighment bridges. Finally shortfall was arrived in the quantity of rice for the receipt of rice at MLS point.

A case study of Rajahmundy MLS point, where in variations of issue and receipt weights with sources of variation effecting gross weight was shown (Table 4). The following were responsible for variations effecting gross, tare and stored-tare weights:

Mechanical variations: When weighbridges tested and legally approved, it is recognized that they are comprised of mechanical and electronic components, which have inherent variability. The weights and measures laws in India and in most of other countries specify the maximum level of relative deviation in reading that is permitted from known test weights, i.e., acceptable relative tolerance of weighbridge as $0.1 \%$ (e.g. +/-40 kg deviation on a 40 tonne load in weighbridge is allowed). Different capacities of weighbridges i.e., 40, 50, 60 and 100 MT were used by MLS points in recording receipts or issues and the all the weighbridges were checked for stamping by Legal Metrology Department. For each truck load, weighbridge showed final net weights in the range of 10-60 kg short (Table 4)

Removable accessories such as tyre, chains and tool box and along with the spare tyres, fuel etc have been identified as one of the major variables in truck weight.

Depending on fuel tank capacity and level, fuel can account for a variation due to filling/ emptying before/after measurement at a particular weighbridge.

Truck configuration also affected tare weight variation. Additional weight will be registered on each reading due to axle "shifts" due to change in the centers of gravity of the truck, if the truck is not properly placed on the platform.

\section{Poor management issues attributable to Handling loss}

The data pertaining to spillage during multiple handling of rice during receipt and issues was presented in Table 5. Non-usable quantity in spilled rice was considered as physical loss.

Rice is stored and handled in re-used jute bags and each bag containing rice undergo at least 6-8 handlings from the start of procurement to reaching retail stores. For each handling, handheld hooks are used by labourers (Plate 2). A minimum of 8 hook 
holes per bag and a maximum of 20 hook holes were observed on gunny bags in most of the MLS point godowns causing bleeding from the bags during storage and during handling causing spillage (Plate 2 and 3). Added to this poor maintenance of godowns with sunken floor with crevices, rodent burrows, poor guarding from birds, non use of dunnage for storage of rice bags resulted in non-usable spillage.

\section{Socio-economic issues in handling loss}

Quantities of handling loss computed for various MLS points were shown in Table 6. More than the technical issues, cultural and social factors including attitudes of labourers strongly affect the nature and magnitude of handling losses. It was observed that there has been a cultural practice of sparing $50-100 \mathrm{~kg}$ of rice per month to the godown sweepers as they are paid meager wages; this is also leading to siphoning of sizeable quantity of rice from the storage godowns. Handling loss quantity is proportionately distributed to the Fair price shop dealer that ultimately leads to reduction in allocated quantity to the poor.

It is of the opinion that the better conditions to the workforce in terms of better emoluments and incentives to sweepers, watchmen and labourers that suffice their livelihood can foster the necessary stimulation to change over time and that helps organization in reducing pilferage and unaccountable losses in long run.

\section{Economic loss due to handling and transit losses}

Estimation of transit and handling losses helps in identifying different operations where losses are high and whether the losses are avoidable. It helps in formulating strategies to reduce losses. However, implementation of corrective measures involve investment and therefore, it is pertinent to estimate the economic value of losses. Hence, monetary value of the losses was estimated at state level with transaction quantity of 2.64 million MT with an average handling and transit loss of $0.276 \%$. Procurement price of rice per $\mathrm{kg}$ to Corporation was considered as Rs. 25/- per kg or Rs. 25,000/- per MT to calculate monetary losses. The economic value of quantitative loss at MLS points due to handling and transit was estimated to be in the tune of Rs. 182.1 millions per annum conservatively.

In conclusions, LS points encounter significant proportion of post-harvest losses caused by various biotic and abiotic factors during receipts from buffer storage point and issues to fair price shops. It also encompasses the losses occurring during the intermediate handling and unscientific storage practices.

Storage godown of MLS point is the most important single factor which can keep the losses caused by insects, rodents and fungi to a minimum level. The entomological and engineering requirements in a MLS point cannot be taken up separately as both are harmonizing to each other.

Major amounts of handling losses are avoidable losses, which actually amounts to the quantity of grains saved for the economy. Nevertheless, ensuring the receipt of exact quantities of quality rice from the buffer storage point is of prime importance.

Any effort to reduce transit and handling losses, must begin with a quantitative assessment of the problem. In absence of previous studies in this regard, it was very difficult to estimate transit and handling losses with precision due to its inherent variability. But it is also a result of many social, cultural and economic factors that hurdles the smooth and efficient flow of food grains under public distribution system from buffer storage godown to consumers. 
Table.1 Details of selected Mandal Level Stock (MLS) points for the study

\begin{tabular}{|c|c|c|c|c|c|c|c|c|c|}
\hline \multirow{2}{*}{$\begin{array}{l}\text { Name of the } \\
\text { District }\end{array}$} & \multirow{2}{*}{$\begin{array}{c}\text { Name of the MLS } \\
\text { Point }\end{array}$} & \multirow[t]{2}{*}{ Category } & \multirow{2}{*}{$\begin{array}{l}\text { Godown } \\
\text { capacity } \\
\text { (MT) }\end{array}$} & \multirow{2}{*}{$\begin{array}{l}\text { Quantity } \\
\text { handled per } \\
\text { month } \\
\text { (MT) }\end{array}$} & \multirow{2}{*}{$\begin{array}{c}\text { Quantity ear } \\
\text { marked for study } \\
\text { per month (MT) }\end{array}$} & \multirow{2}{*}{$\begin{array}{c}\text { Name of the } \\
\text { Buffer godown }\end{array}$} & \multirow{2}{*}{$\begin{array}{c}\text { Distance from } \\
\text { MLS point } \\
(\mathbf{k m})\end{array}$} & \multicolumn{2}{|c|}{ Mode of weighment } \\
\hline & & & & & & & & Receipts & Issues \\
\hline Srikakulam & Srikakulam & Unscientific & 300 & 1549 & 200 & CWC, Aampolu & 6 & Platform scale & Platform scale \\
\hline Vizianagaram & Vizianagaram & Scientific (semi) & 1000 & 1200 & 500 & $\begin{array}{l}\text { AMC, } \\
\text { Jiyyammavalasa }\end{array}$ & 10 & Platform scale & Platform scale \\
\hline Visakhapatnam & Marripalem & Scientific (semi) & 2000 & 1833 & 500 & AMC, Pendurthi & 18 & Platform scale & Platform scale \\
\hline East Godavari & Rajahmundry & Scientific* & 1500 & 2500 & 500 & $\begin{array}{l}\text { CWC, Lalacheruvu } \\
\text { PWS Rajolu }\end{array}$ & $\begin{array}{l}3.5 \\
13\end{array}$ & Weighbridge & Platform scale \\
\hline West Godavari & Tadepalligudem & Unscientific & 2500 & 2000 & 500 & $\begin{array}{l}\text { CWC, } \\
\text { Tadepalligudem }\end{array}$ & 10 & Weighbridge & Weighbridge \\
\hline Krishna & Vuyyuru & Scientific & 1000 & 750 & 500 & $\begin{array}{l}\text { SWC, Uppuluru } \\
\text { CWC, Nidamanuru }\end{array}$ & $\begin{array}{l}15 \\
25\end{array}$ & Weighbridge & Platform scale \\
\hline Guntur & Guntur Rural & Scientific (semi) & 500 & 1000 & 200 & $\begin{array}{l}\text { CWC, Vadlamudi } \\
\text { CWC, Pedakakani }\end{array}$ & $\begin{array}{l}17 \\
10\end{array}$ & Platform scale & Platform scale \\
\hline Prakasam & Singarayakonda & Scientific & 2500 & 720 & 500 & $\begin{array}{l}\text { AMC, Ongole } \\
\text { AMC Gullapalli }\end{array}$ & $\begin{array}{l}28 \\
10\end{array}$ & Platform scale & Platform scale \\
\hline Nellore & Podalakuru & Scientific (semi) & 1000 & 470 & 470 & $\begin{array}{l}\text { CWC, } \\
\text { Nellore }\end{array}$ & 30 & Weighbridge & Weighbridge \\
\hline Chittoor & Punganuru & Scientific & 2000 & 1500 & 500 & PWS, Yerpedu & 180 & Platform scale & Platform scale \\
\hline Kurnool & Kurnool & Scientific (semi) & 2500 & 2611 & 500 & $\begin{array}{l}\text { SWC, } \\
\text { Kurnool }\end{array}$ & 9 & Weighbridge & Weighbridge \\
\hline Kadapa & Kadapa & Scientific & 1200 & 1670 & 500 & $\begin{array}{l}\text { CWC, } \\
\text { Kadapa }\end{array}$ & 2.5 & Weighbridge & Platform scale \\
\hline Ananthapur & Hindupur & Scientific (semi) & 1500 & 1500 & 500 & $\begin{array}{l}\text { CWC, Nandyala, } \\
\text { SWC, } \\
\text { Timmanacheruvu }\end{array}$ & $\begin{array}{l}250 \\
170\end{array}$ & Weighbridge & Weighbridge \\
\hline
\end{tabular}

AMC- Agricultural Market Committee; CWC - Central Warehousing Corporation; SWC - State Warehousing Corporation; PWS -Private Warehouse Service

*Scientific godowns: RCC structure whose plinth is elevated to $1.2 \mathrm{~m}$ above ground level to make it rodent proof, damp proof flooring, convenient for movement of grains, weather proof and capable of controlled aeration with sealable openings, facilitates complete godown or stack fumigation and yet economical

Semi scientific godowns: Structure whose plinth is elevated to $1.2 \mathrm{~m}$ above ground level and fulfils at least $30 \%$ of above criteria mentioned for scientific godowns

Unscientific godowns: Structures that fail to fulfil at least $30 \%$ of above criteria mentioned for scientific godowns 
Table.2 Average transit and handling losses at various MLS points

\begin{tabular}{|c|c|c|c|}
\hline MLS Point & $\begin{array}{l}\text { Rice handled } \\
\text { during study } \\
\text { (MT) }\end{array}$ & $\begin{array}{c}\text { Transit losses } \\
(\%)\end{array}$ & $\begin{array}{c}\text { Handling losses } \\
(\%)\end{array}$ \\
\hline Srikakulam & 1029.873 & $\begin{array}{l}0.109-0.401 \\
\quad(0.264)\end{array}$ & $\begin{array}{l}0.028-0.111 \\
\quad(0.080)\end{array}$ \\
\hline Vizianagaram & 2081.580 & $\begin{array}{l}0.152-0.715 \\
\quad(0.211)\end{array}$ & $\begin{array}{c}0.004-0.137 \\
\quad(0.078)\end{array}$ \\
\hline Marripalem & 2514.488 & $\begin{array}{l}0.207-0.545 \\
\quad(0.217)\end{array}$ & $\begin{array}{l}0.03-0.193 \\
(0.103)\end{array}$ \\
\hline Rajahmundry & 2337.758 & $\begin{array}{c}0.095-0.127 \\
(0.10)\end{array}$ & $\begin{array}{c}0.002-0.103 \\
(0.04)\end{array}$ \\
\hline Tadepalligudem & 2323.845 & $\begin{array}{c}0.000-0.009 \\
(0.0018)\end{array}$ & $\begin{array}{l}0.036-0.261 \\
\quad(0.128)\end{array}$ \\
\hline Vuyyuru & 2351.569 & $\begin{array}{l}0.143-1.024 \\
\quad(0.504)\end{array}$ & $\begin{array}{l}0.049-0.415 \\
(0.142)\end{array}$ \\
\hline Guntur Rural & 1398.380 & $\begin{array}{l}0.138-0.245 \\
\quad(0.186)\end{array}$ & $\begin{array}{l}0.037-0.190 \\
(0.09)\end{array}$ \\
\hline Singarayakonda & 2376.790 & $\begin{array}{l}0.248-0.622 \\
\quad(0.279)\end{array}$ & $\begin{array}{l}0.040-0.115 \\
(0.07)\end{array}$ \\
\hline Podalakuru & 1809.533 & $\begin{array}{l}0.040-0.201 \\
\quad(0.130)\end{array}$ & $\begin{array}{l}0.040-0.101 \\
\quad(0.08)\end{array}$ \\
\hline Punganuru & 2471.073 & $\begin{array}{l}0.020-0.191 \\
\quad(0.124)\end{array}$ & $\begin{array}{l}0.070-0.112 \\
\quad(0.089)\end{array}$ \\
\hline Kadapa & 2583.570 & $\begin{array}{l}0.107-0.255 \\
\quad(0.172)\end{array}$ & $\begin{array}{l}0.053-0.341 \\
\quad(0.197)\end{array}$ \\
\hline Kurnool & 2554.329 & $\begin{array}{l}0.212-0.806 \\
\quad(0.239)\end{array}$ & $\begin{array}{l}0.203-0.570 \\
\quad(0.313)\end{array}$ \\
\hline Hindupur & 2558.683 & $\begin{array}{c}0.050-0.419 \\
(0.08)\end{array}$ & $\begin{array}{l}0.070-0.223 \\
(0.147)\end{array}$ \\
\hline Total /Average & 28391.472 & $0.194 \pm 0.121$ & $0.082 \pm 0.07$ \\
\hline
\end{tabular}

Table.3 Testing of significance of $\mathrm{T} \& \mathrm{H}$ losses with interaction among independent parameters

\begin{tabular}{|l|l|c|c|c|c|c|}
\hline \multicolumn{1}{|c|}{ Source } & $\begin{array}{c}\text { Dependent } \\
\text { Variable }\end{array}$ & $\begin{array}{c}\text { Type III } \\
\text { Sum of } \\
\text { Squares }\end{array}$ & df & $\begin{array}{c}\text { Mean } \\
\text { Square }\end{array}$ & \multicolumn{1}{|c|}{ F } & Sig. \\
\hline Corrected & TransitLoss & $1.876^{\mathrm{a}}$ & 16 & 0.117 & 5.756 & .000 \\
\hline Model & HandlingLoss & $0.547^{\mathrm{b}}$ & 16 & 0.034 & 3.331 & .001 \\
\hline Intercept & TransitLoss & 3.638 & 1 & 3.638 & 178.572 & .000 \\
\cline { 2 - 8 } & HandlingLoss & 1.288 & 1 & 1.288 & 125.477 & .000 \\
\hline MLSP & TransitLoss & 1.535 & 12 & 0.128 & 6.280 & .000 \\
\hline
\end{tabular}




\begin{tabular}{|l|l|l|c|c|c|c|}
\hline \multirow{4}{*}{ Month } & HandlingLoss & 0.546 & 12 & 0.046 & 4.433 & .000 \\
\hline \multirow{2}{*}{ Error } & TransitLoss & 0.341 & 4 & 0.085 & 4.183 & .005 \\
\cline { 2 - 8 } & HandlingLoss & 0.001 & 4 & 0.000 & 0.024 & .999 \\
\hline \multirow{2}{*}{ Total } & TransitLoss & 0.978 & 48 & 0.020 & & \\
\cline { 2 - 8 } & HandlingLoss & 0.493 & 48 & 0.010 & & \\
\hline \multirow{2}{*}{$\begin{array}{l}\text { Corrected } \\
\text { Total }\end{array}$} & TransitLoss & 6.492 & 65 & & & \\
\cline { 2 - 8 } & HandlingLoss & 2.328 & 65 & & & \\
\hline
\end{tabular}

Table.4 Case study at Rajamundry MLS point showing variation in Issue and Receipt weight due to weighbridge intricacies

\begin{tabular}{|c|c|c|c|c|c|}
\hline $\begin{array}{c}\text { Truck } \\
\text { No }\end{array}$ & $\begin{array}{c}\text { Tare weight } \\
\text { of truck at } \\
\text { BSG Issues } \\
\text { (Kg) }\end{array}$ & $\begin{array}{c}\text { Tare weight } \\
\text { of truck at } \\
\text { MLSP } \\
\text { Receipts } \\
\text { (Kg) }\end{array}$ & $\begin{array}{c}\text { Differen } \\
\text { ce (Kg) }\end{array}$ & $\begin{array}{c}\text { Probable reasons for } \\
\text { variation }\end{array}$ & $\begin{array}{c}\text { Shortage in } \\
\text { quantity of } \\
\text { rice at MLS } \\
\text { point (kg) }\end{array}$ \\
\hline $\mathbf{1}$ & 10470 & 10490 & 20 & Mechanical variations & 80 \\
\hline $\mathbf{2}$ & 12280 & 12300 & 20 & Mechanical variations & 60 \\
\hline $\mathbf{3}$ & 12160 & 12190 & 30 & Mechanical variations & 60 \\
\hline $\mathbf{4}$ & 12150 & 12160 & 10 & Mechanical variations & 30 \\
\hline $\mathbf{5}$ & 12260 & 12290 & 30 & Mechanical variations & 50 \\
\hline $\mathbf{6}$ & 10450 & 10450 & 0 & - & 50 \\
\hline $\mathbf{7}$ & 12160 & 12180 & 20 & Mechanical variations & 70 \\
\hline $\mathbf{8}$ & 12150 & 12180 & 30 & Mechanical variations & 60 \\
\hline $\mathbf{9}$ & 12140 & 12160 & 20 & Mechanical variations & 80 \\
\hline $\mathbf{1 0}$ & 12160 & 12200 & 40 & Mechanical variations & 70 \\
\hline $\mathbf{1 1}$ & 12240 & 12370 & 130 & Fuel top up & 160 \\
\hline $\mathbf{1 2}$ & 12380 & 12470 & 90 & Removable accessories & 50 \\
\hline $\mathbf{1 3}$ & 10560 & 10600 & 40 & Removable accessories & 140 \\
\hline $\mathbf{1 4}$ & 12260 & 12380 & 120 & Fuel top up & 90 \\
\hline $\mathbf{1 5}$ & 12290 & 12270 & -20 & Improper placement on & 10 \\
\hline $\mathbf{1 6}$ & 10680 & 10710 & 30 & Mechanical variations & 30 \\
\hline $\mathbf{1 7}$ & 12190 & 12210 & 20 & Mechanical variations & 110 \\
\hline $\mathbf{1 8}$ & 12280 & 12280 & 0 & - & 90 \\
\hline $\mathbf{1 9}$ & 10610 & 10590 & -20 & Improper placement on & 5 \\
\hline $\mathbf{2 0}$ & 12270 & 12310 & 40 & Mlatform & \\
\hline $\mathbf{2 1}$ & 12250 & 12280 & 30 & Mechanical variations & 80 \\
\hline & & & & & 100 \\
\hline
\end{tabular}




\begin{tabular}{|c|c|c|c|c|c|}
\hline 22 & 10410 & 10450 & 40 & Mechanical variations & 105 \\
\hline 23 & 12190 & 12220 & 30 & Mechanical variations & 110 \\
\hline 24 & 12180 & 12220 & 40 & Mechanical variations & 121 \\
\hline 25 & 12340 & 12360 & 20 & Mechanical variations & 120 \\
\hline 26 & 12320 & 12360 & 40 & Mechanical variations & 140 \\
\hline 27 & 12330 & 12350 & 20 & Mechanical variations & 80 \\
\hline 28 & 12300 & 12350 & 50 & Removable accessories & 70 \\
\hline 29 & 12300 & 12350 & 50 & Removable accessories & 30 \\
\hline 30 & 12190 & 12210 & 20 & Mechanical variations & 65 \\
\hline 31 & 12265 & 12290 & 25 & Mechanical variations & 40 \\
\hline 32 & 10415 & 10450 & 35 & Mechanical variations & 130 \\
\hline 33 & 12085 & 12150 & 65 & Removable accessories & 105 \\
\hline 34 & 10435 & 10465 & 30 & Mechanical variations & 45 \\
\hline 35 & 12275 & 12295 & 20 & Mechanical variations & 60 \\
\hline 36 & 10440 & 10475 & 35 & Mechanical variations & 45 \\
\hline 37 & 12185 & 12215 & 30 & Mechanical variations & 20 \\
\hline 38 & 12190 & 12220 & 30 & Mechanical variations & 60 \\
\hline 39 & 12270 & 12290 & 20 & Mechanical variations & 70 \\
\hline 40 & 12130 & 12240 & 110 & Fuel top up & 140 \\
\hline 41 & 10430 & 10450 & 20 & Mechanical variations & 45 \\
\hline 42 & 12220 & 12240 & 20 & Mechanical variations & 38 \\
\hline 43 & 12165 & 12185 & 20 & Mechanical variations & 60 \\
\hline 44 & 12300 & 12330 & 30 & Mechanical variations & 60 \\
\hline 45 & 12290 & 12305 & 15 & $\begin{array}{l}\text { Improper placement on } \\
\text { platform }\end{array}$ & 55 \\
\hline 46 & 12085 & 12115 & 30 & Mechanical variations & 70 \\
\hline 47 & 12240 & 12260 & 20 & Mechanical variations & 40 \\
\hline 48 & 10345 & 10375 & 30 & Mechanical variations & 89.6 \\
\hline 49 & 12090 & 12100 & 10 & Mechanical variations & 30 \\
\hline $\mathbf{5 0}$ & 12270 & 12290 & 20 & Mechanical variations & 50 \\
\hline 51 & 12145 & 12155 & 10 & Mechanical variations & 30 \\
\hline 52 & 12310 & 12340 & 30 & Mechanical variations & 70 \\
\hline 53 & 12275 & 12315 & 40 & Mechanical variations & 80 \\
\hline 54 & 12260 & 12290 & 30 & Mechanical variations & 40 \\
\hline 55 & 12235 & 12265 & 30 & Mechanical variations & 90 \\
\hline 56 & 10405 & 10425 & 20 & Mechanical variations & 70 \\
\hline 57 & 12050 & 12070 & 20 & Mechanical variations & 80 \\
\hline 58 & 12320 & 12350 & 30 & Mechanical variations & 115 \\
\hline 59 & 12330 & 12375 & 45 & Mechanical variations & 125 \\
\hline 60 & 12265 & 12300 & 35 & Mechanical variations & 105 \\
\hline
\end{tabular}




\begin{tabular}{|c|c|c|c|c|c|}
\hline $\mathbf{6 1}$ & 12320 & 12360 & 40 & Mechanical variations & 120 \\
\hline $\mathbf{6 2}$ & 12165 & 12190 & 25 & Mechanical variations & 100 \\
\hline $\mathbf{6 3}$ & 10335 & 10370 & 35 & Mechanical variations & 65 \\
\hline $\mathbf{6 4}$ & 12240 & 12265 & 25 & Mechanical variations & 135 \\
\hline $\mathbf{6 5}$ & 12285 & 12320 & 35 & Mechanical variations & 115 \\
\hline $\mathbf{6 6}$ & 10325 & 10345 & 20 & Mechanical variations & 75 \\
\hline $\mathbf{6 7}$ & 10310 & 10325 & 15 & Mechanical variations & 60 \\
\hline $\mathbf{6 8}$ & 12255 & 12280 & 25 & Mechanical variations & 85 \\
\hline $\mathbf{6 9}$ & 10590 & 10605 & 15 & Mechanical variations & 55 \\
\hline $\mathbf{7 0}$ & 12140 & 12165 & 25 & Mechanical variations & 95 \\
\hline $\mathbf{7 1}$ & 10600 & 10620 & 20 & Mechanical variations & 70 \\
\hline $\mathbf{7 2}$ & 12220 & 12245 & 25 & Mechanical variations & 80 \\
\hline $\mathbf{7 3}$ & 12135 & 12160 & 25 & Mechanical variations & 92 \\
\hline $\mathbf{7 4}$ & 10590 & 10605 & 15 & Mechanical variations & 55 \\
\hline $\mathbf{7 5}$ & 12295 & 12315 & 20 & Mechanical variations & 70 \\
\hline $\mathbf{7 6}$ & 10520 & 10540 & 20 & Mechanical variations & 55 \\
\hline $\mathbf{7 7}$ & 12165 & 12200 & 35 & Mechanical variations & 75 \\
\hline $\mathbf{7 8}$ & 12245 & 12265 & 20 & Mechanical variations & 85 \\
\hline $\mathbf{7 9}$ & 12370 & 12410 & 40 & Mechanical variations & 90 \\
\hline $\mathbf{8 0}$ & 12315 & 12350 & 35 & Mechanical variations & 115 \\
\hline $\mathbf{8 1}$ & 12265 & 12290 & 25 & Mechanical variations & 95 \\
\hline $\mathbf{8 2}$ & 10465 & 10490 & 25 & Mechanical variations & 95 \\
\hline $\mathbf{8 3}$ & 8575 & 8590 & 15 & Mechanical variations & 40 \\
\hline $\mathbf{8 4}$ & 11995 & 12035 & 40 & Mechanical variations & 120 \\
\hline $\mathbf{8 5}$ & 12355 & 12395 & 40 & Mechanical variations & 125 \\
\hline $\mathbf{8 6}$ & 8590 & 8605 & 15 & Mechanical variations & 40 \\
\hline $\mathbf{8 7}$ & 10435 & 10470 & 35 & Mechanical variations & 100 \\
\hline $\mathbf{8 8}$ & 11945 & 11985 & 40 & Mechanical variations & 130 \\
\hline $\mathbf{8 9}$ & 10250 & 10270 & 20 & Mechanical variations & 75 \\
\hline $\mathbf{9 0}$ & 11935 & 11965 & 30 & Mechanical variations & 40 \\
\hline $\mathbf{9 1}$ & 12425 & 12445 & 20 & Mechanical variations & 75 \\
\hline $\mathbf{9 2}$ & 12270 & 12295 & 25 & Mechanical variations & 80 \\
\hline $\mathbf{9 3}$ & 12275 & 12305 & 30 & Mechanical variations & 95 \\
\hline & & & & & \\
\hline
\end{tabular}


Table.5 Data showing spillage during handling of rice during stage 1 and 2 at MLS point

\begin{tabular}{|c|c|c|c|c|c|c|c|c|c|c|c|}
\hline \multirow[t]{3}{*}{ S.No. } & \multirow{3}{*}{$\begin{array}{l}\text { Name of the MLS } \\
\text { Point }\end{array}$} & \multicolumn{6}{|c|}{ Cumulative spillage loss for study period } & \multirow{2}{*}{\multicolumn{3}{|c|}{ Total }} & \multirow[t]{3}{*}{ Reasons for spillage } \\
\hline & & \multicolumn{3}{|c|}{ Stage 1} & \multicolumn{3}{|c|}{ Stage 2} & & & & \\
\hline & & $\begin{array}{l}\text { Spillage } \\
\text { (kg) }\end{array}$ & $\begin{array}{l}\text { Usable } \\
\text { (kg) }\end{array}$ & $\begin{array}{l}\text { Non- } \\
\text { usable } \\
\text { (kg) }\end{array}$ & $\begin{array}{l}\text { Spillage } \\
\text { (kg) }\end{array}$ & $\begin{array}{l}\text { Usable } \\
\text { (kg) }\end{array}$ & $\begin{array}{l}\text { Non- } \\
\text { usable } \\
\text { (kg) }\end{array}$ & $\begin{array}{l}\text { Spillage } \\
\text { (kg) }\end{array}$ & $\begin{array}{c}\text { Usable } \\
\text { (kg) }\end{array}$ & $\begin{array}{l}\text { Non- } \\
\text { usable } \\
\text { (kg) }\end{array}$ & \\
\hline 1 & SRIKAKULAM & 111.4 & 88.6 & 22.8 & 223 & 166.3 & 56.7 & 334.4 & 254.9 & 79.5 & Hook holes \\
\hline 2 & VIZIANAGARAM & 1524.5 & 1170 & 354.5 & 1475.5 & 1084 & 391.5 & 3000 & 2254 & 746 & Poor quality of gunnys, Hook holes \\
\hline 3 & MARRIPALEM & 4117 & 3870 & 247 & 623 & 521 & 102 & 4740 & 4391 & 349 & Poor quality of gunnys, Hook holes \\
\hline 4 & RAJHMUNDRY & 406 & 297 & 109 & 544.5 & 437 & 107.5 & 950.5 & 734 & 216.5 & Poor quality of gunnys, Hook holes \\
\hline 5 & TADEPALLIGUDEM & 980 & 832 & 148 & 1124 & 927 & 197 & 2104 & 1759 & 345.0 & $\begin{array}{l}\text { Hook holes, rodents, poor quality of } \\
\text { gunnys, contamination of rice by rodent } \\
\text { faecal pellets }\end{array}$ \\
\hline 6 & VUYYURU & 253 & 201.25 & 51.75 & 562 & 496.5 & 65.5 & 815 & 697.75 & 117.25 & Hook holes, poor floor condition, \\
\hline 7 & GUNTUR RURAL & 452 & 359.5 & 92.5 & 249.5 & 148 & 101.5 & 701.5 & 507.5 & 194 & Hook holes, poor floor condition, \\
\hline 8 & SINGARAYAKONDA & 1425 & 1230 & 195 & 622 & 401 & 221 & 2047 & 1631 & 416 & $\begin{array}{l}\text { Hook holes, poor quality of gunnys, } \\
\text { contamination of rice by rodent faecal } \\
\text { pellets }\end{array}$ \\
\hline 9 & PODALAKURU & 573.9 & 503.7 & 70.2 & 439.6 & 390.1 & 49.5 & 1013.5 & 893.8 & 119.7 & Hook holes \\
\hline 10 & KADAPA & 3328 & 2920 & 408 & 2679 & 1944 & 735 & 6007 & 4864 & 1143 & $\begin{array}{l}\text { Hook holes, poor floor condition, poor } \\
\text { quality gunnys }\end{array}$ \\
\hline 11 & KURNOOL & 167 & 128 & 39 & 285 & 225 & 60 & 452 & 353 & 99 & Hook holes \\
\hline 12 & HINDUPUR & 567.25 & 484.35 & 82.9 & 761 & 635.8 & 125.2 & 1328.25 & 1120.15 & 208.1 & Hook holes \\
\hline 13 & PUNGANURU & 899.5 & 775 & 124.5 & 975.9 & 798.1 & 177.8 & 1875.4 & 1573.1 & 302.3 & Hook holes \\
\hline
\end{tabular}


Table.6 Handling loss quantities recorded at various MLS points during study period

\begin{tabular}{|c|c|c|c|c|c|c|c|c|}
\hline \multirow[t]{3}{*}{ S.No. } & \multirow[t]{3}{*}{$\begin{array}{l}\text { Name of the MLS } \\
\text { Point }\end{array}$} & \multicolumn{6}{|c|}{$\begin{array}{l}\text { Handling loss quantity (Receipt -Issue-Usable quantity), } \\
\text { kg }\end{array}$} & \multirow[t]{3}{*}{ Major Reasons for Handling loss } \\
\hline & & \multicolumn{6}{|c|}{ Month } & \\
\hline & & 1st & 2nd & 3rd & 4th & 5th & Average & \\
\hline 1 & SRIKAKULAM & 154.80 & 91.00 & 177.00 & 50.60 & 202.40 & 135.16 & Pilferage \& Siphoning during interim storage \\
\hline 2 & VIZIANAGARAM & 133.00 & 54.00 & 151.64 & 571.00 & 154.50 & 212.83 & Pilferage \& Siphoning during interim storage \\
\hline 3 & MARRIPALEM & 626.40 & 811.20 & 328.52 & 131.00 & 199.00 & 419.22 & Pilferage \& Siphoning during interim storage \\
\hline 4 & RAJHMUNDRY & 35.00 & 18.00 & 119.50 & 298.00 & 108.51 & 115.80 & $\begin{array}{l}\text { Variation due to weighbridge and platform } \\
\text { scale measurement }\end{array}$ \\
\hline 5 & TADEPALLIGUDEM & 443.24 & 369.90 & 49.00 & 1281.00 & 644.00 & 557.43 & Pilferage \& Siphoning during interim storage \\
\hline 6 & VUYYURU & 747.14 & 314.00 & 126.58 & 739.74 & 1181.06 & 621.70 & $\begin{array}{l}\text { Pilferage \& Siphoning during interim storage, } \\
\text { variation due to W-P measurement }\end{array}$ \\
\hline 7 & GUNTUR RURAL & 487.50 & 98.00 & 160.00 & 707.00 & 248.50 & 340.20 & Pilferage \& Siphoning during interim storage \\
\hline 8 & SINGARAYAKONDA & 393.00 & 225.00 & 291.00 & 141.00 & 216.00 & 253.20 & Pilferage \& Siphoning during interim storage \\
\hline 9 & PODALAKURU & 470.74 & 21.14 & 166.38 & 257.52 & 205.80 & 224.32 & Pilferage \& Siphoning during interim storage \\
\hline 10 & KADAPA & 124.00 & 1164.00 & 1512.00 & 920.00 & 867.00 & 917.40 & $\begin{array}{l}\text { Pilferage \& Siphoning during interim storage } \\
\text {, variation due to W-P measurement }\end{array}$ \\
\hline 11 & KURNOOL & 2854.74 & 1047.10 & 2240.00 & 1618.12 & 1177.98 & 1787.59 & Pilferage \& Siphoning during interim storage \\
\hline 12 & HINDUPUR & 346.06 & 934.50 & 901.12 & 691.50 & 252.00 & 625.04 & Pilferage \& Siphoning during interim storage \\
\hline 13 & PUNGANURU & 477.00 & 270.32 & 92.82 & 481.08 & 150.30 & 294.30 & Pilferage \& Siphoning during interim storage \\
\hline
\end{tabular}


Plate.1 Different modes of weighment

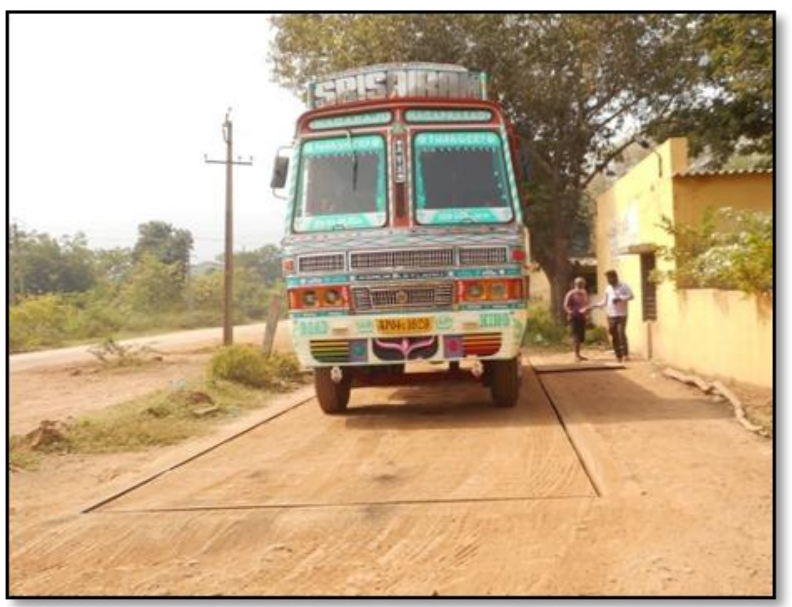

Weighbridge

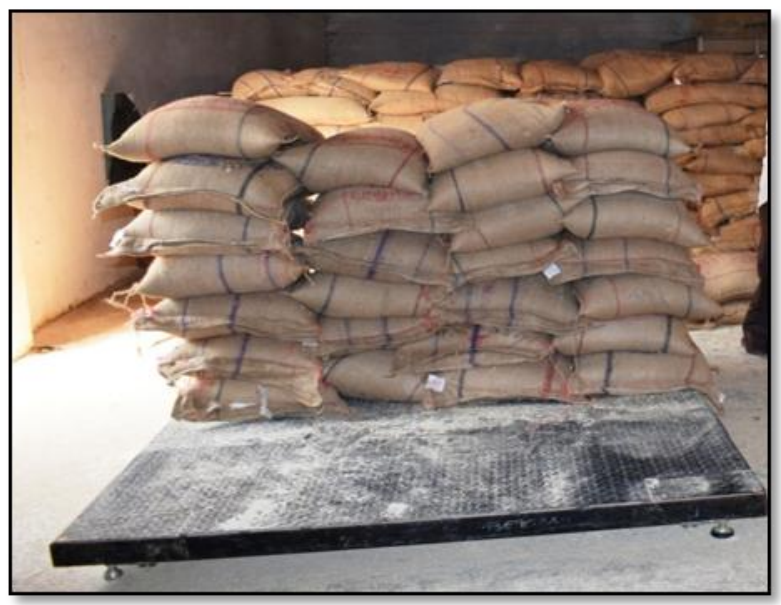

Platform scale

Plate.2 Different types of hooks used by hamalies for handling rice bags
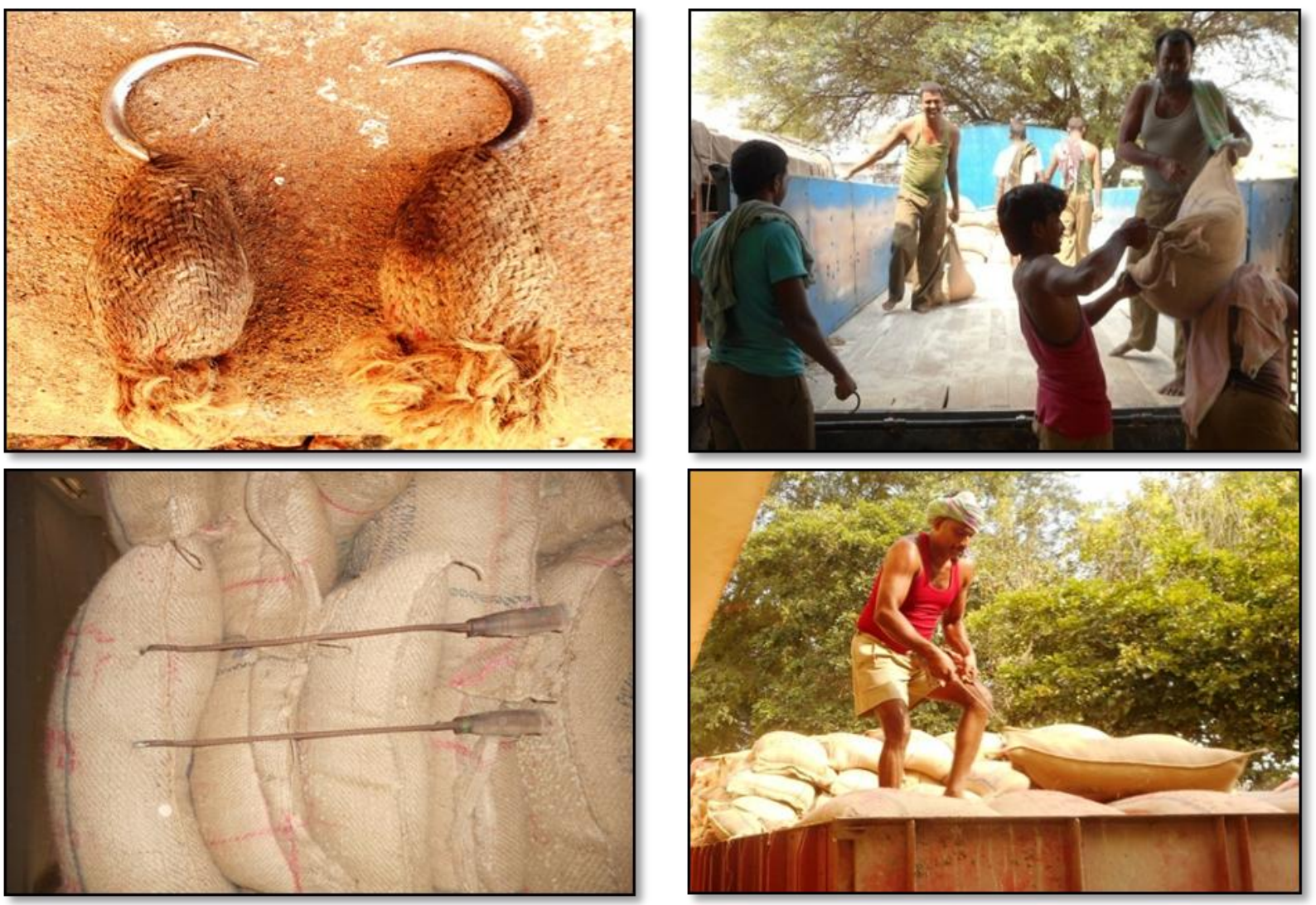
Plate.3 Bleeding of rice from poor quality gunnies
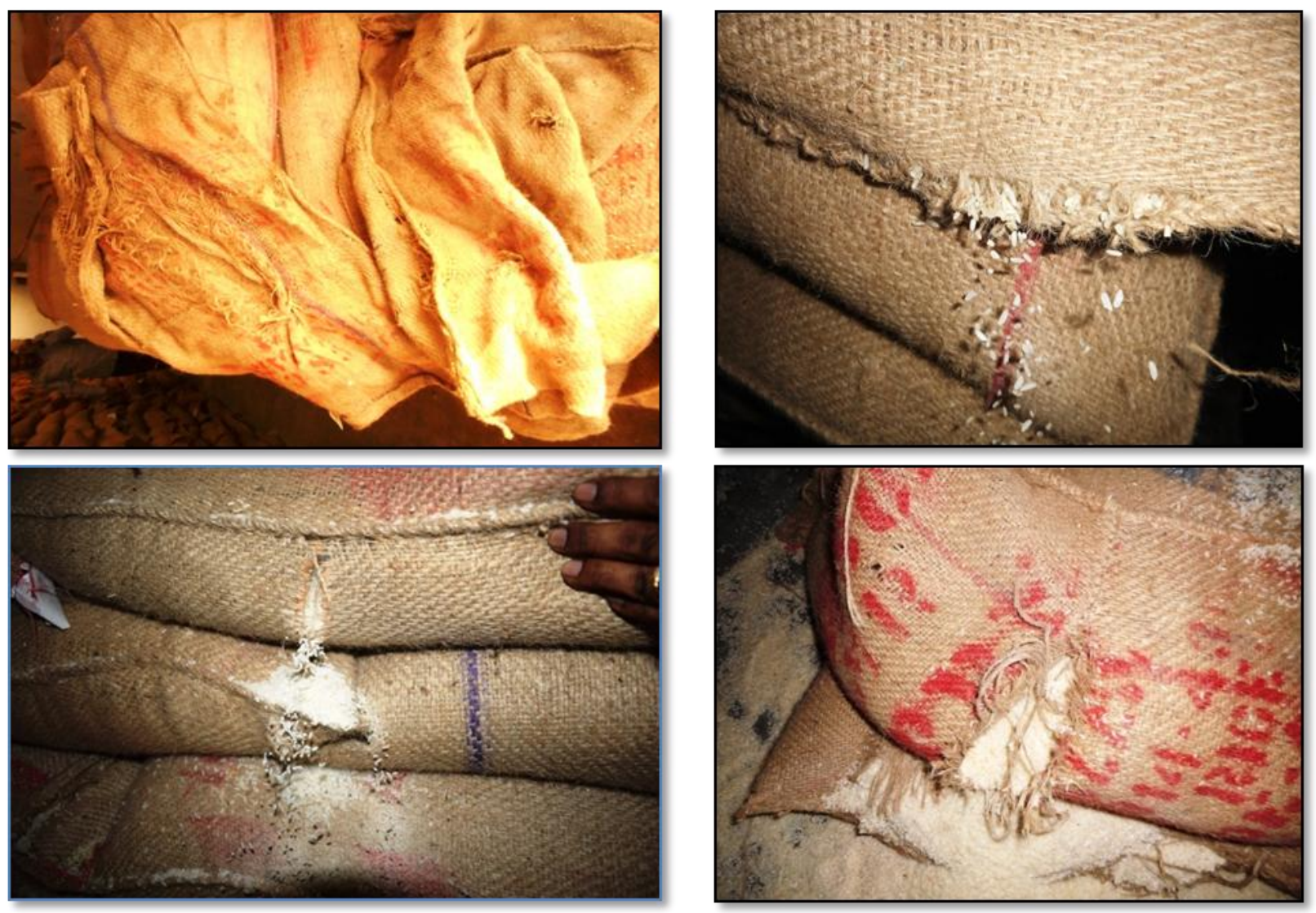

Average transit losses in MLS points were estimated to be in the range of 0.08 to $0.23 \%$. Major factors contributed to the transit loss were differences in mode of weighment and their relative tolerance levels for measurement and unused spillage losses during transit. Average handling losses in MLS points were estimated to be in the range of 0.04 to $0.19 \%$. Average transit and handling losses were assessed to be $0.276 \%$ and annual economic loss to the State's exchequer due to transit and handling loss was estimated to be Rs.182.1 millions. The inherent variability in handling and transit losses renders extrapolation from one loss situation or from one time period to another difficult, but not impossible, without being counterproductive. Presently, no study or reliable scientific data on transit and storage losses exists. Under these situations, the loss values obtained in the study in those particular situations should be used only as an indicative or representative of particular kind of loss in highly similar situations.

\section{Acknowledgement}

The authors wish to acknowledge the financial support received from Andhra Pradesh State Civil Supplies Corporation Limited., Vijayawada and Government of Andhra Pradesh, India for conducting the study.

\section{References}

Alavi, H.R., Htenas, A., Kopicki, R., Shepherd, A.W. and Clarete, R. 2012. Trusting trade and the private sector for food security in Southeast Asia; World Bank Publications: Washington, DC, 
USA.

Basavaraja, H., Mahajanashetti, S.B. and Naveen, C.U. 2007. Economic analysis of post-harvest losses in food grains in India: A case study of Karnataka. Agricultural Economics Research Review. 20: 117-126.

Comptroller and Auditor General Report. 2017. Government of India, New Delhi.

Jha, S.N., Vishwakarma, R.K., Ahmad, T., Rai, A. and Dixit, A.K. 2015. A report on assessment of quantitative harvest and post-harvest losses of major crops and commodities in India. ICAR-All India Coordinated Research Project on Post-Harvest Technology, ICARCIPHET, PAU, Ludhiana: 67.

Kannan, E., Kumar, P., Vishnu, K. and Abraham, H. 2013. Assessment of pre and post-harvest losses of rice and redgram in Karnataka. Research Report: IX/ADRTC/15.

Nanda, S.K., Vishwakarma, R.K., Bathla, H.V.L., Rai, A. and Chandra, P. 2012. Harvest and post-harvest losses of major crops and livestock produce in India. ICAR-All India Coordinated
Research Project on Post-Harvest Technology, ICAR-CIPHET, PAU, Ludhiana. pp: 137.

Rao, I.Y.R.K 1993. Andhra Pradesh: An experiment in food security. Economic and Political Weekly, September 28(37).

Sreeramulu, N., Chimalwar, P.J., Verma, V.K. Singh H.P. and Bhatia G.R. 2005. Post- harvest profile of Wheat. Directorate of Marketing \& Inspection (DMI), Ministry of Agriculture, India. P: $\quad$ 73. Available at: http://agmarknet.nic.in/profile_wheat.pd f

Surajit, D. 2009. Public distribution of rice in Andhra Pradesh: Efficiency and reform options. Economic and Political Week, December 19, 44(51): 70-77.

World Bank, 1986. Poverty and hunger issues and options for food security in developing countries, World bank, Washington DC.

World Bank, 1997. India, Andhra Pradesh: Agenda for economic reforms, Report No 15901, Washington DC.

\section{How to cite this article:}

Vishnu Vardhan, S., S.V.S. Gopala Swamy, D. Sandeep Raja and John Wesley, B. 2020. Transit and Handling Losses of Rice in Public Distribution of Andhra Pradesh, India- A Case Study. Int.J.Curr.Microbiol.App.Sci. 9(07): 3136-3151. doi: https://doi.org/10.20546/ijcmas.2020.907.369 